\title{
PENGARUH SWITCHING BARRIER DAN CITRA MEREK TERHADAP LOYALITAS PELANGGAN PADA PRODUK INTERBIS \\ (STUDI KASUS PADA PT. MULTIMAS SUMBER HARAPAN PADANG) \\ INFLUENCE OF SWITCHING BARRIER AND BRAND IMAGE ON CUSTOMER LOYALTY IN INTERBIS PRODUCT \\ (CASE STUDY ON PT MULTIMAS SUMBER HARAPAN PADANG)
}

\author{
Dessy Darma Sari ${ }^{1)}$, Agussalim $\mathbf{M}^{2)}$, Sunreni ${ }^{3)}$ \\ Jurusan Manajemen, Fakultas Ekonomi, Universitas Ekasakti - AAI Padang 1) 2) 3) 4) \\ dessydarma11@gmail.com; sunreni50@gmail.com
}

\begin{abstract}
Abstrak
Penelitian ini bertujuan untuk mengetahui dan menganalisis pengaruh switching barrier dan citra merek terhadap loyalitas pelanggan pada produk Interbis di PT. Multimas Sumber Harapan Padang baik secara parsial maupun simultan, untuk mengetahui dan menganalisis pengaruh switching barrier terhadap loyalitas pelanggan pada produk Interbis melalui citra merek di PT. Multimas Sumber Harapan Padang dan untuk mengetahui dan menganalisis pengaruh citra merek terhadap loyalitas pelanggan pada produk Interbis melalui switching barrier di PT. Multimas Sumber Harapan Padang. Metode pengumpulan data yang digunakan dalam penelitan ini yaitu dengan menggunakan riset lapangan dan riset pustaka. Metode analisis data dalam penelitian ini menggunakan regresi linear berganda dan path analisis. Hasil penelitian ini menunjukka bahwa: 1) Switching Barrier berpengaruh positif dan signifikan terhadap Loyalitas Pelanggan karena thitung 7,020 lebih besar dari t tabel dan nilai sig 0,000 lebih kecil dari $\alpha$ $(0,05)$. 2) Citra Merek berpengaruh positif dan signifikan terhadap Loyalitas Pelanggan karena thitung 10,200 lebih besar dari t tabel dan nilai sig 0,000 lebih kecil dari a (0,05). 3) Switching Barrier dan Citra Merek berpengaruh signifikan secara bersama sama terhadap Loyalitas Pelanggan (Y) karena $F$ hitung 196,297 lebih besar dari F tabel dan nilai sig 0,000 lebih kecil dari a (0,05). 4) Switching Barrier berpengaruh secara tidak langsung terhadap Loyalitas Pelanggan melalui Citra Merek karena nilai analisis path sebesar 0,363 dimana lebih besar dari $\alpha(0,05)$. 5) Citra Merek berpengaruh secara tidak langsung terhadap Loyalitas Pelanggan melalui Switching Barrier karena nilai analisis path sebesar 0,252 dimana lebih besar dari $\alpha(0,05)$. 6) Hasil analisis determinasi diperoleh angka Adjusted $R$ Square sebesar 0,804 atau sebesar 80,4\%. Hal ini menunjukan persentase sumbangan variabel Switching Barrier dan Citra Merek terhadap Loyalitas Pelanggan sebesar 80,4\% dan sisanya dipengaruhi varibel diluar penelitian.
\end{abstract}

Kata Kunci : Switching Barrier, Citra Merek, Loyalitas Pelanggan.

\begin{abstract}
This study aims to determine and analyze the effect of switching barrier and brand image to customer loyalty on Interbis products in PT. Multimas Sumber Harapan Padang either partially or simultaneously, to know and analyze the effect of switching barrier to customer loyalty on Interbis product through brand image in PT. Multimas Sumber Harapan Padang and to know and analyze the influence of brand image to customer loyalty on Interbis product through switching barrier at PT. Multimas Sumber Harapan Padang. Data collection methods used in this research is by using field research and literature research. Methods of data analysis in this study using multiple linear regression and path analysis. The results of this study indicate that: 1) Switching Barrier has positive and significant effect on Customer Loyalty because $t$ count 7.020 bigger than $t$ table and the value of sig 0.000 is smaller than $\alpha(0,05)$. 2) Brand image has positive and significant impact on Customer Loyalty because t arithmetic 10,200 bigger than $t$ table and value of sig 0.000 smaller than $\alpha(0,05)$. 3) Switching Barrier and Brand Image have a significant effect simultaneously on Customer Loyalty (Y) because F count is 196,297 bigger than F table and the value of sig 0.000 is smaller than $\alpha(0,05)$. 4) Switching Barrier indirectly affect Customer Loyalty through Brand Image because the value of path analysis of 0.363 which is greater than $\alpha(0.05)$. 5) Brand image indirectly affect Customer Loyalty through Switching Barrier because path analysis value equal to 0,252 which is bigger than a $(0,05)$. 6) The results of determination analysis obtained Adjusted $R$ Square number of 0.804 or $80.4 \%$. This shows the percentage contribution of variable Switching Barrier and Brand Image to Customer Loyalty of 80,4\% and the rest influenced by variable outside of research. Keywords : $\quad$ Switching Barrier, Brand Image, Customer Loyalty.
\end{abstract}




\section{PENDAHULUAN \\ Latar Belakang}

Perusahaan sebagai suatu organisasi pada umumnya mempunyai tujuan tertentu yang hendak dicapai. Dalam usaha untuk mencapai tujuan-tujuan tersebut, perusahaan mempunyai cara ataupun metode tersendiri untuk mengembangkan usahanya, Menarik minat calon pembeli dan mempertahankan para pelangganya. Persaingan perusahaan saat ini bukan hanya sebatas menarik konsumen untuk mengkonsumsi produk atau jasa yang dihasilkan oleh perusahaan melainkan menerapkan berbagai cara untuk mempertahankan para pelangganya, karena pada dasarnya Menciptakan pelanggan yang loyal adalah hal penting bagi sebuah perusahaan, karena biaya untuk menarik pelanggan yang baru ternyata lebih besar daripada biaya untuk mempertahankan pelanggan yang ada.

Banyak pakar pemasaran berpendapat loyalitas pelanggan adalah muara yang sebenarnya dari rangkaian aktivitas pemasaran, bukan kepuasan pelanggan. Kesimpulan ini dikuatkan oleh kenyataan bahwa pelanggan yang puas tak menjamin akan melakukan pembelian berulang (repeat purchase) melainkan pelanggan loyal yang melakukannya. Akan tetapi, selain dari kepuasan pelanggan, ada batasan-batasan yang juga menentukan loyalitas. Salah satu penyebab loyalitas konsumen terhadap suatu produk adalah kekuatan dari produk itu sendiri, semakin kuat atau terkenal sebuah produk maka konsumen akan lebh cendrung memilihnya (Kotler, 2015).

Perusahaan dalam usaha memasarkan produk perlu menanmkan citra merek yang positif pada benak konsumen. Menurut Kotler (2015), citra merek adalah persepsi dan keyakinan yang dilakukan oleh konsumen. Merek yang kuat dalam jangka panjang akan memberikan hasil yang lebih besar dan dapat memberikan nilai lebih untuk sebuah produk baru yang dikeluarkan oleh produsen tersebut, sehingga akan mempermudah perusahaan dalam melakukan perluasan lini produk. Citra merek dapat memberi manfaat baik bagi konsumen maupun produsen, diantaranya akan membangun loyalitas, yang dimana loyalitas tersebut tersebut akan mendorong pelanggan untuk melakukan konsumsi berulang.

Merek diposisikan pada kepercayaan dan nilai yang kuat yang melibatkan emosi di dalamnmya. Pemahaman kepercayaan merek berbedan dengan kepercayaan interpersonal, karena merek merupakan simbol yang sulit untuk merespon pelanggan. Menurut Lau dan Lee dalam Arlan (2015), kepercayaan terhadap merek adalah kemauan mempercayai merek dengan segala resikonya karena adanya harapan yang dijanjikan oleh merek dalam memberikan hasil yang positif bagi konsumen. Hubungan yang positif ini harus dilakukan secara konsisten.

Dengan tingginya citra merek sebuah produk dimata konsumen, maka kemungkinan konsumen beralih ke produk lain yang sejenis semakin kecil. Menurut Supriadi (2015:61), hambatan pindah (switching barrier) mengacu pada tingkat kesulitan untuk berpindah ke penyedia jasa lain ketika pelanggan tidak puas dengan jasa yang diterima. Switching barrier merupakan langkah yang dapat digunakan oleh perusahaan untuk mempertahankan pelanggannya dan menjaga kesetiaan pelanggannya. Switching barrier yang tinggi ditandai dengan tingginya resiko yang harus ditanggung oleh pelanggan jika mereka ingin berpindah ke merek lain. Hambatan untuk berpindah ini tidak selalu resiko economic value, yang berupa tingginya biaya yang harus ditanggung oleh pelanggan jika mereka ingin berganti merek, tetapi bisa juga berkaitan dengan resiko fungsi, sosial bahkan ritual.

PT. Multimas Sumber Harapan Padang merupakan perusahaan yang bergerak di dalam bidang pendistribusian makanan berupa biscuit di kota Kota Padang dan sekitarnya. Biscuit yang dijual adalah merek Interbis dan Danes. Produk biscuit merek Interbis merupakan produk yang paling laku dibandingkan dengan produk danes.

Dalam kegiatan operasionalnya PT. Multimas Sumber Harapan Padang mempekerjakan sales untuk mendistribusikan produknya. Sales kemudian dibagi menjadi beberapa blok daerah pemasarannya. Sales berupaya mencari konsumen untuk membeli produknya, dapat dikatakan sales merupakan ujung tombak penjualan perusahaan. Kemampuan sales dalam melayani kebutuhan pelanggan menjadi faktor utama agar konsumen menjadi loyal dan selalu mengambil produk biscuit dari PT. Multimas Sumber Harapan Padang. Selain sales dituntut memberikan pelayanan yang baik kepada pelanggan, produk biscuit yang ditawarkan PT. Multimas Sumber Harapan Padang merupakan produk ternama yang telah dipromosikan melaui media cetak ataupun elektronik oleh produsennya.

\section{Rumusan Masalah}

Berdasarkan latar belakang masalah, maka dapat dirumuskan permasalahannya sebagai berikut :

1. Apakah switching barrier dan citra merek berpengaruh terhadap loyalitas pelanggan pada produk Interbis di PT. Multimas Sumber Harapan Padang baik secara parsial maupun simultan?

2. Apakah switching barrier berpengaruh terhadap loyalitas pelanggan pada produk Interbis melalui citra merek di PT. Multimas Sumber Harapan Padang? 
3. Apakah citra merek berpengaruh terhadap loyalitas pelanggan pada produk Interbis melalui switching barier di PT. Multimas Sumber Harapan Padang?

\section{LANDASAN TEORI \\ Switching barrier}

Menurut Klara (2015) Konsep switching barrier muncul dan dipertimbangkan agak terlambat dalam literatur pemasaran. Asal usulnya kembali ke tahun 80an, di bidang ekonomi industri, terkait dengan pengaruh biaya switching di pasaran. Ada beberapa alasan untuk keadaan darurat ini, yang terpenting adalah transisi dari pasar penjual ke pasar pembeli. Dalam konteks pasar yang jenuh, yang menyebabkan persaingan ketat, perusahaan berkewajiban untuk mengurus klien mereka agar dapat meningkatkan daya saing mereka dan memastikan keuntungan mereka. Menurut Supriadi (2015:61), hambatan pindah (switching barrier) mengacu pada tingkat kesulitan untuk berpindah ke penyedia jasa lain ketika pelanggan tidak puas dengan jasa yang diterima.

Hambatan pindah dapat berbentuk kendala finansial, sosial dan psikologis yang dirasakan seorang pelanggan ketika berpindah ke penyedia jasa baru. Oleh karena itu, semakin tinggi switching barrier maka pelanggan semakin dipaksa untuk tetap pada produk yang digunakannya saat ini. Switching barrier didefinisikan sebagai inkontinensia ekonomi dan psikologis yang harus dialami konsumen saat beralih ke penyedia layanan baru (Chung, 2017).

Pada saat pelanggan berpikir bahwa mereka tidak memiliki alternative lain dari suatu level pelayanan, ataupun sitra lain yang lebih baik, maka kemungkinan pelanggan tersebut untuk berpindah ke penyedia produk atau jasa lain akan sangat kecil. Daya Tarik alternatif merupakan suatu komponen penting bagi perusahaan dalam membangun switching barrier. Menurut Supriadi (2015:62), daya tarik alternatif mengacu pada reputasi, citra, dan kualitas jasa yang diharapkan lebih unggul atau lebih cocok dibanding penyedia jasa lain. Tudung (2016) menjelaskan kepuasan pelanggan merupakan salah satu faktor penting yang dapat menyebabkan retensi pelanggan, kepercayaan, dan switching barrier. Hambatan berpindah yang dirumuskan didefinisikan sebagai penilaian konsumen atas sumber daya dan peluang yang diperlukan untuk melakukan tindakan berpindah, atau alternatifnya, kendala yang mencegah tindakan berpindah (Seiedeh, 2015).

\section{Indikator Switching barrier}

Menurut Budi Suharjo dalam Pusporini (2015) substansi pengukuran loyalitas konsumen salah satunya adalah switching barrier.
Hambatan berpindah, yaitu menyangkut hambatan yang dirasakan konsumen bila ia berpindah dari satu produk ke produk lain. Hambatan ini tidak hanya didasarkan pertimbangan nilai-nilai ekonomis, melainkan juga bekaitan dengan faktor psikologis, sosial, fungsional dan ritual. Faktor-faktor inilah yang membuat para pelanggan merasa kesulitan ketika ingin berpindah ke produk lain. Variabel tersebut terdiri dari :

1. Nilai ekonomis, merupakan segala sasuatu yang diinginkan konsumen dalam produk atau jasa. Sebagian konsumen melihat nilai sebagai suatu pertukaran yang seimbang antara harga yang dibayarkan dengan manfaat kualitas dari produk atau jasa yang diperoleh.

2. Psikologis, adalah upaya mental, rasa tidak sanggup, kecemasan atau ketakutan emosi pribadi pelanggan yang terjadi pada saat menilai berbagai alternatif jasa. Faktor psikologis timbul dari keadaan fisiologis tertentu seperti kebutuhan untuk diakui, harga diri atau kebutuhan untuk diterima oleh lingkungannya.

3. Faktor sosial, terdiri atas kelompok referensi yaitu seluruh kelompok yang mempunyai pengaruh langsung terhadap sikap atau perilaku seseorang, keluarga ataupun peran dan status, yaitu posisi seseorang dalam setiap kelompok.

4. Fungsional, sangat erat kaitannya dengan kualitas, yaitu kemampun suatu penyedia jasa untuk menjalankan fungsi-fungsinya. Apakah nantinya memuaskan atau tidak memuaskan bagi pelanggan.

5. Ritual, adalah upacara tentang kebenaran religius yang berarti. Dalam membangun kesetiaan pelanggan, hal ini adalah aktifitas rutin untuk menaikkan perusahaan kepada tujuan-tujuan serta nilai-nilai yang diinginkan. Tindakan setiap hari ini seperti misalnya penampilan pribadi di tempat kerja, memuji pelanggan dan sambutan yang hangat dan tepat.

\section{Citra Merek}

Sebuah merek yang terkenal dan terpercaya merupakan aset yang tidak ternilai. Keahlian yang paling unik dari pemasaran yang professional adalah kemampuannya untuk menciptakan, memelihara, melindungi, dan meningkatkan merek. Aaker dalam Romadhoni (2015: 76) menyatakan merek adalah cara membedakan sebuah nama atau symbol seperti logo, trademark, atau desain kemasan yang dimaksudkan untuk mengidentifikasikan produk atau jasa dari satu produsen atau satu kelompok produsen dan untuk membedakan produk atau jasa itu dari produsen pesaing. Citra merek adalah kumpulan persepsi tentang sebuah merek 
yang saling berkaitan yang ada dalam pikiran manusia (Ouwersoot dan Tudorica dalam Nandya, 2016)

UU Merek No.15 Tahun 2001 Pasal 1 Ayat 1 menyatakan bahwa Merek adalah tanda yang berupa gambar, nama kata, hurufhuruf, angkaangka, susunan warna atau kombinasi dari unsurunsur tersebut yang memiliki daya pembeda dan digunakan dalam kegiatan perdagangan barang dan jasa. Definisi ini memiliki kesamaan dengan definisi versi American Marketing Association yang menekankan peranan merek sebagai identifier dan differentiation. Merek sangat bermanfaat bagi konsumen dan produsen.

\section{Indikator Citra Merek}

M Ramadhoni (2015 : 80) menyatakan bahwa brand image memiliki 3 variabel pendukung, yaitu:

1. Citra Pembuat/ Perusahaan (Corporate Image) merupakan sekumpulan asosiasi yang dipersepsikan konsumen terhadap perusahaan yang membuat suatu produk atau jasa.

2. Citra Pemakai (User Image) merupakan sekumpulan asosiasi yang dipersepsikan konsumen terhadap pemakai yang menggunakan suatu barang atau jasa.

3. Citra Produk (Product Image) merupakan sekumpulan asosiasi yang dipersepsikan konsumen terhadap suatu produk.

\section{Loyalitas Pelanggan}

Menurut Tjiptono (2015) "Perilaku pembelian ulang semata mata menyangkut pembelian merek tertentu yang sama secara berulang kali (bisa dikarenakan memang hanya satu satu nya merk yang tersedia, merk termurah dan sebagainya). Kotler dan Keller (2015) mengungkapkan loyalitas adalah "komitmen yang dipegang secara mendalam untuk membeli atau mendukung kembali produk atau jasa yang disukai di masa depan meski pengaruh situasi dan usaha pemasaran berpotensi menyebabkan pelanggan beralih".

Menurut Hasan (2017) bahwa loyalitas pelanggan adalah pelanggan yang hanya tidak membeli ulang suatu barang dan jasa misalnya dengan merekomendasikan orang lain untuk membeli. Sedangkan menurut Griffin (2015), adalah seorang konsumen dikatkan setia atau loyal apabila konsumen menunjukan perilaku pembelian secara teratur atau terdapat suatu kondisi dimana mewajibkan konsumen membeli paling Sedikit dua kali dalam selang waktu tertentu. Loyalitas merupakan kesetiaan customer terhadap penyedia jasa yang telah memberikan pelayanan kepadanya (Supriyatmini dalam Gusti, 2017).

\section{Indikator Loyalitas Pelanggan}

Dalam hal ini penelitian yang digunakan mengacu kepada teori yang diungkapkan Jill Griffin. Beberapa indikator yang digunakan untuk mengukur variabel loyalitas pelanggan adalah:

1. Melakukan pembelian ulang secara teratur, pembelian ulang secara teratur dikenal sebagai konsep generic, loyalitas merek menujukkan kecenderungan konsumen untuk membeli sebuah merek tertentu dengan tingkat konsistensi yang tinggi.

2. Melakukan pembelian diluar lini produk/jasa. Pelanggan bukan hanya membeli produk satu jenis sesudah yang lainnya, tetapi mereka membeli aksesoris untuk produk mereka, yang dimana mungkin pelanggan menambah item-item dari produk yang dibelinya.

3. Merekomendasikan produk. Pelanggan yang selalu merekomendasikan produk kepada orang lain adalah aset terbesar bagi perusahaan, dimna pelanggan ini selain merekomendasikan akan selalu membeli produk dan merek perusahaan, pelanggan akan menjadi juru bicara yang baik pada pelanggan lain dan pelanggan akan marah apabila ada orang lain menjelek-jelekkan merek perusahaan.

\section{Kerangka Konseptual}

Sesuai dengan permasalahan di atas, maka dibuatlah suatu susunan berupa kerangka konseptual sebagai berikut :

\section{Gambar 1 Kerangka Konseptual Regresi}

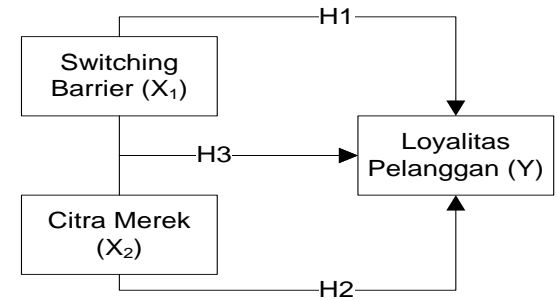

Selain kerangka konseptual untuk regresi berganda, penulis juga menyusun kerangka konseptual untuk analisa path.

\section{Gambar 2 Kerangka Konseptual Analisis Path X1 Terhadap Y Melalui X2}

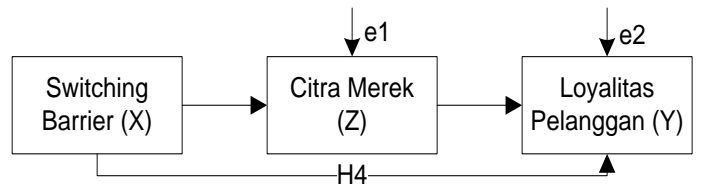


Gambar 3 Kerangka Konseptual Analisis Path X2 Terhadap Y Melalui X1

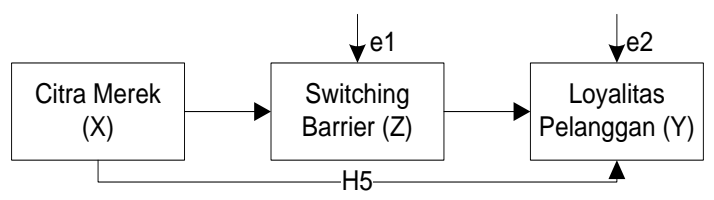

\section{Hipotesis}

Berdasarkan kerangka konseptual diatas maka hipotesis pda penelitian ini dapat disimpulkan sebagai berikut :

H1. Diduga switching barrier berpengaruh terhadap loyalitas pelanggan pada produk Interbis di PT. Multimas Sumber Harapan Padang.

H2. Diduga citra merek berpengaruh terhadap loyalitas pelanggan pada produk Interbis di PT. Multimas Sumber Harapan Padang.

H3. Diduga switching barrier dan citra merek berpengaruh terhadap loyalitas pelanggan pada produk Interbis di PT. Multimas Sumber Harapan Padang.

H4. Diduga switching barrier berpengaruh terhadap loyalitas pelanggan melalui citra merek pada produk Interbis di PT. Multimas Sumber Harapan Padang.

H5. Diduga citra merek berpengaruh terhadap loyalitas pelanggan melalui switching barrier pada produk Interbis di PT. Multimas Sumber Harapan Padang.

\section{METODE PENELITIAN}

\section{Metode Pengumpulan Data}

1. Riset Lapangan (field research), yaitu penelitian dengan mengadakan peninjauan langsung pada lokasi perusahaan dengan maksud memperoleh data dan informasi melalui wawancara, observasi dan kuesioner.

2. Riset Kepustakaan (library research), yaitu upaya untuk memperoleh data yang dilakukan oleh penulis melalui buku-buku sebagai landasan teori dalam penelitian.

\section{Teknik Pengumpulan Data}

Teknik pengumpulan data yang digunakan dalam penelitian ini adalah dengan menggunakan angket, yaitu teknik pengumpulan data yang dilakukan dengan cara memberikan seperangkat pertanyaan atau pernyataan kepada pelanggan PT. Multimas Sumber Harapan.

\section{Jenis Dan Sumber Data}

Jenis data yang digunakan dalam penelitian ini adalah data kuantitatif yang dijadikan kualitatif mengikuti skala likert, yaitu data yang diperoleh dalam bentuk jawaban terhadap pertanyaan yang diberikan. Data kualitatif dalam penelitian ini bersumber dari jawaban kueisioner yang diberikan penulis kepada pelanggan PT. Multimas Sumber Harapan.
Sumber data yang digunakan dalam penelitian ini adalah:

1. Data Primer, adalah data yang diperoleh secara langsung dari sumber aslinya. Pengumpulan data ini biasanya dilakukan dengan membagikan kuesioner kepada obyek penelitian dan diisi secara langsung oleh responden.

2. Data Sekunder, adalah data yang dikumpulkan secara tidak langsung dari sumbernya. Data yang didapatkan dari arsip yang dimiliki organisasi / instansi, studi pustaka, penelitian terdahulu, dan jurnal yang berhubungan dengan permasalahan yang akan diteliti.

\section{Populasi Dan Sampel}

Populasi adalah suatu kelompok yang terdiri dari objek atau subjek yang mempunyai kualitas dan karakteristik tertentu yang ditetapkan oleh peneliti untuk dipelajari dan kemudian ditarik kesimpulan (Sugiyono, 2017:17). Populasi yang digunakan dalam penelitian ini adalah pelaggan PT. Multimas Sumber Harapan Padang tahun 2017 berjumlah 2.134 orang.

Sampel adalah sebagian dari populasi yang memiliki karakteristik yang sama dengan populasi. Adapun jumlah sampel dari populasi di atas dihitung dengan menggunakan rumus slovin dengan tingkat signifikansi 0,1 sehingga didapatkan sampel sebanyak 96 orang.

\section{Uji Validitas}

Untuk menjawab permasalahan pertama dilakukan uji validitas, menurut Arikunto (2012) dikatakan bahwa validitas adalah suatu ukuran yang menunjukkan tingkat-tingkat kevalidan, atau kesahihan suatu instrumen.Suatu instrumen yang valid atau sahih mempunyai validitas yang tinggi, sebaliknya instrumen yang kurang valid memiliki validitas yang rendah. Sebuah instrumen dikatakan valid apabila mampu mengukur apa yang diinginkan. Tinggi rendahnya validitas instrumen menunjukkan sejauh mana data yang terkumpul tidak menyimpang dari gambaran tentang validitas yang dimaksud.

Valid tidaknya suatu item instrumen dapat diketahui dengan cara mengkorelasikan masingmasing skor item dengan skor total dan melakukan koreksi terhadap nilai koefisien korelasi yang overestimasi. Hal ini dikarenakan agar tidak terjadi koefisien item total yang overestimasi (estimasi nilai yang lebih tinggi dari yang sebenarnya). Atau dengan cara lain, analisis ini menghitung korelasi tiap item dengan skor total (teknik bivariate pearson), tetapi skor total disini tidak termasuk skor item yang akan dihitung. Sebagai contoh pada kasus di atas kita akan menghitung item 1 dengan skor total, 
berarti skor total didapat dari penjumlahan skor item 2 sampai item 10. Perhitungan teknik ini cocok digunakan pada skala yang menggunakan item pertanyaan yang sedikit, karena pada item yang jumlahnya banyak penggunaan korelasi bivariate (tanpa koreksi) efek overestimasi yang dihasilkan tidak terlalu besar. Dari output spss dilihat pada Corrected Item - Total Correlation, nilai ini kemudian kita bandingkan dengan nilai $r$ tabel, $r$ tabel dicari pada signifikansi 0,05 dengan uji 2 sisi dan jumlah data yang digunakan. (Imam Ghazali, 2015).

\section{Uji Reliabilitas}

Imam Ghazali (2015) mendefinisikan reliabilitas sebagai suatu instrumen yang cukup dapat dipercaya untuk digunakan sebagai alat pengumpul data karena instrumen tersebut sudah baik. Instrumen yang baik tidak akan bersifat tendensius mengarahkan responden untuk memilih jawaban tertentu. Instrumen yang sudah dapat dipercaya, yang reliabel akan menghasilkan data yang dapat dipercaya pula. Uji reliabilitas adalah indeks yang menunjukkan sejauh mana alat ukur yang dapat dipercaya atau diandalkan untuk diuji. Nilai tiap-tiap item sebaiknya $\geq 0.40$ sehingga membuktikan bahwa item tersebut dapat dikatakan punya reliabilitas Konsistensi Internal. Item-item yang punya koefisien korelasi $<0.40$ akan dibuang kemudian Uji Reliabilitas item diulang dengan tidak menyertakan item yang tidak reliabel tersebut. Demikian terus dilakukan hingga Koefisien Reliabilitas masing-masing item adalah $\geq 0.40$ (Imam Ghazali, 2015).

\section{Uji Normalitas}

Uji normalitas bertujuan untuk menguji apakah dalam model regresi, variabel pengganggu atau residual memiliki distribusi normal. Seperti diketahui bahwa uji t dan F mengasumsikan bahwa nilai residual mengikuti distribusi normal. Kalau asumsi ini dilanggar maka uji statistik menjadi tidak valid untuk jumlah sampel kecil. Ada dua cara untuk mendeteksi apakah residual berdistribusi normal atau tidak yaitu dengan analisis grafik dan uji statistik. Untuk menguji apakah data berdistribusi normal atau tidak dilakukan uji statistik Kolmogorov-Smirnov Test. Residual berdistribusi normal jika memiliki nilai signifikansi >0,05 (Imam Ghozali, 2015).

\section{Uji Multikolinearitas}

Menurut Imam Ghozali (2015) uji multikolinieritas bertujuan untuk menguji apakah model regresi ditemukan adanya korelasi antar variabel bebas (independen). Untuk menguji multikolinieritas dengan cara melihat nilai VIF masing-masing variabel independen, jika nilai
VIF < 10, maka dapat disimpulkan data bebas dari gejala multikolinieritas.

\section{Uji Heteroskedasisitas}

Uji heterokedastisitas bertujuan menguji apakah dalam model regresi terjadi ketidaksamaan variance dari residual satu pengamatan ke pengamatan yang lain. Ada beberapa cara yang dapat dilakukan untuk melakukan uji heteroskedastisitas, yaitu uji grafik plot, uji park, uji glejser, dan uji white. Pengujian pada penelitian ini menggunakan Grafik Plot antara nilai prediksi variabel dependen yaitu ZPRED dengan residualnya SRESID. Tidak terjadi heteroskedastisitas apabila tidak ada pola yang jelas, serta titik-titik menyebar di atas dan di bawah angka 0 pada sumbu Y. (Imam Ghozali, 2015).

\section{Path Analysis (Analisis Jalur)}

Path Analysis digunakan untuk menjawab rumusan masalah kedua dan ketiga. Analsis Jalur (Path Analysis) merupakan pengembangan dari analisis regresi, sehingga analisis regresi dapat dikatakan sebagai bentuk khusus dari analisis jalur (regression is special case of path analysis). Analisis jalur digunakan untuk melukiskan dan menguji model hubungan antar variabel yang berbentuk sebab akibat (bukan bentuk hubungan interaktif / reciprocal).Dengan demikian dalam model hubungan antar variable tersebut, terdapat variable independen yang dalam hal ini disebut variable Eksogen (Exogenous), dan variable dependen yang disebu tvariabel Endogen (endogenous) (Agussalim M, 2015). Dan pada penelitian kali ini, peneliti menggunakan diagram jalur (Path Diagram).Diagram jalur ini digunakan berdasarkan kerangka berfikir yang dikembangkan dari teori yang digunakan untuk penelitian.

\section{Gambar 4 Diagram Jalur X1 Terhadap Y Melalui X2}

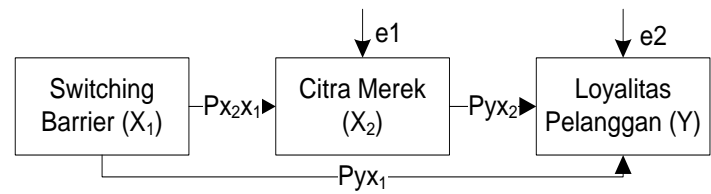

Sehingga terbentuknya sub struktur sebagai berikut:

$$
\begin{aligned}
& \mathrm{X} 2=\mathrm{Px} 2 \mathrm{X} 1+\mathrm{e} 1 \\
& \mathrm{Y}=\mathrm{Pyx} 1+\mathrm{Pyx} 2+\mathrm{e} 2
\end{aligned}
$$


Gambar 4 Diagram Jalur X2 Terhadap Y Melalui

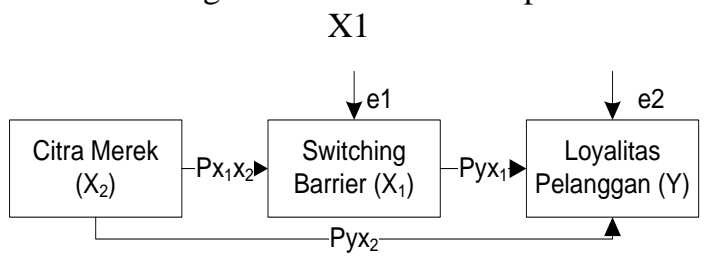

Sehingga terbentuknya sub struktur sebagai berikut:

$$
\begin{aligned}
& \mathrm{X} 1=\mathrm{Px} 1 \mathrm{x} 2+\mathrm{e} 1 \\
& \mathrm{Y}=\mathrm{Pyx} 1+\mathrm{Pyx} 2+\mathrm{e} 2
\end{aligned}
$$

\section{Regresi Linear Berganda}

Analisis kuantitatif digunakan untuk menjawab permasalahan ketiga, dengan model analisa regresi linear berganda, dan koefisien determinasi (Agussalim M, 2015:82), bentuk persamaan sebagai berikut :

$$
\begin{aligned}
& \mathrm{Y}=\alpha+\mathrm{b} 1 \mathrm{X} 1+\mathrm{b} 2 \mathrm{X} 2+\mathrm{e} \\
& \text { Dimana }: \\
& \mathrm{Y}=\text { Loyalitas Pelanggan } \\
& \mathrm{a}=\text { nilai konstanta } \\
& \mathrm{b} 1=\text { Switching Barrier } \\
& \mathrm{b} 2=\text { Citra Merek } \\
& \mathrm{x} 1=\text { Switching Barrier } \\
& \mathrm{x} 2=\text { Citra Merek } \\
& \mathrm{e}=\text { residual error }
\end{aligned}
$$

Untuk memudahkan dalam analisis data pembahasan penelitian ini, maka dalam pengolahan data dan analisis data digunakan program computer, yaitu program SPSS. (Agussalim Manguluang, 2015:88)

\section{Koefesien Determinasi}

Koefisien determinasi (R2) pada intinya mengukur seberapa jauh kemampuan model dalam menerangkan variasi variabel dependen. Nilai koefisien determinasi adalah antara nol dan satu. Nilai R2 yang kecil berarti kemampuan variabel-variabel independen dalam menjelaskan variasi variabel dependen amat terbatas. Nilai yang mendekati satu berarti variabel-variabel independen memberikan hampir semua informasi yang dibutuhkan untuk memprediksi variasi variabel dependen (Imam Ghozali, 2015).

\section{Uji t}

Pengujian hipotesis secara parsial antara variabel bebas $(\mathrm{X})$ terhadap variabel tak bebas (Y), digunakan Uji Student (Uji-t), (Agussalim M, 2015:98) dengan rumus sebagai berikut :

$$
\begin{aligned}
t_{b i} & =\frac{\frac{b_{i}}{s_{b i}}}{=}=\text { untuk i }=1 \\
& =\sqrt{\frac{S^{2} y: x}{\sum_{x} 2}}
\end{aligned}
$$

Dimana :

$t_{b i}=$ adalah nilai t-hitung dari masing-masing variabel $\mathrm{Xi}$

$b_{i}=$ adalah nilai parameter dari masingmasing variabel $\mathrm{Xi}$

$S_{b i}=$ adalah nilai simpangan baku dari masing-masing variabel $\mathrm{Xi}$

$$
S^{2} y \cdot x=\frac{\frac{1}{J K K}}{{ }^{n-k-1}} \text { dan } \sum \mathrm{x} 2=\sum \mathrm{x} 2-{ }^{\frac{1}{n}}\left(\sum \mathrm{X}\right) 2
$$

Nilai t-tabel pada tabel distribusi student ditentukan dengan rumus $=\mathrm{t}(\alpha / 2)$ :(N-k-1) kriteria pengujian hipotesis:

$\mathrm{H} 0$ ditolak dan Ha diterima apabila t-hitung $\geq$ t-tabel atau Sig (prob) $<\alpha=5 \%$

H0 diterima dan Ha ditolak apabila t-hitung < t-tabel atau Sig (prob) $\geq \alpha=5 \%$

Dalam penelitian ini, hasil pengolahan data didapatkan dengan menggunakan program pengolahan data statistik SPSS versi 20.

\section{Uji F}

Pengujian hipotesis secara serempak (simultan) antara variabel bebas (Xi) terhadap variabel tak bebas (Y), digunakan Uji Fisher (Uji-F), (Agussalim M, 2015:98) dengan rumus sebagai berikut :

$$
\text { Fhitung }=\frac{\frac{J K R}{R K K}}{R}=\frac{\frac{J K K}{2-k-1}}{N-1}
$$

Dimana : b2 $\sum \mathrm{x} 2 \mathrm{y}$

JKR (Jumlah Kuadrat Regresi) $=$ b1 $\sum x 1 y+$

JKK (Jumlah Kuadrat Kesalahan) $=\sum \mathrm{y} 2-$ (b1 $\left.2 \mathrm{x} 1 \mathrm{y}+\mathrm{b} 2 \sum \mathrm{x} 2 \mathrm{y}\right)$

Setelah diperoleh nilai F-hitung, selanjutnya dibandingkan dengan nilai F-tabel, dengan kriteria pengujian sebagai berikut:

$\mathrm{H} 0$ ditolak jika F0 $\geq$ Ftab atau Sig (prob) $<\alpha$ $=5 \%$, H0 diterima jika F0 < Ftab atau sig (prob) $\geq \alpha=5 \%$. Dalam penelitian ini, hasil pengolahan data didapatkan dengan menggunakan program pengolahan data statistik SPSS versi 20.

\section{HASIL DAN PEMBAHASAN Uji Validitas Switching Barrier (X1)}

Dengan mempergunakan bantuan dari software SPSS versi 20, maka pengujian validitas instrumen, dimana nilai validitas dapat dilihat pada kolom Coreccted Item-Total Correlation. Jika angka korelasi yang didapat lebih besar dari pada angka kritik ( $\mathrm{r}$ hitung $>\mathrm{r}$ tabel ) maka instrumen tersebut dinyatakan valid. Dalam penelitian ini angka kritik adalah $\mathrm{N}=96$, maka angka kritik untuk uji coba validitas dalam penelitian ini adalah 0,1986. Hasil uji validitas 
variabel Switching Barrier (X1), dapat dilihat pada tabel 1 sebagai berikut :

Tabel 1 Hasil Uji Validitas Variabel Switching Barrier (X1)

\begin{tabular}{|c|c|}
\hline & Corrected Item-Total Correlation \\
\hline $\mathrm{x} 101$ &, 424 \\
\hline $\mathrm{x} 102$ &, 638 \\
\hline $\mathrm{x} 103$ &, 615 \\
\hline $\mathrm{x} 104$ &, 575 \\
\hline $\mathrm{x} 105$ &, 475 \\
\hline $\mathrm{x} 106$ &, 620 \\
\hline $\mathrm{x} 107$ &, 644 \\
\hline $\mathrm{x} 108$ &, 711 \\
\hline $\mathrm{x} 109$ &, 516 \\
\hline $\mathrm{x} 110$ &, 681 \\
\hline $\mathrm{x} 111$ &, 698 \\
\hline $\mathrm{x} 112$ &, 639 \\
\hline $\mathrm{x} 113$ &, 685 \\
\hline $\mathrm{x} 114$ &, 564 \\
\hline $\mathrm{x} 115$ &, 466 \\
\hline \multicolumn{2}{|c|}{ Sumber : Data Primer yang Diolah } \\
\hline
\end{tabular}

Berdasarkan tabel 1 diatas seluruh pertanyaan variabel Switching Barrier (X1) dinyatakan valid dikarenakan seluruh nilai Correlation berada diatas nilai $r$ tabel $(0,1986)$, dan seluruh item pernyataan dapat digunaan untuk pengujian selanjutnya.

Uji Validitas Citra Merek (X2)

Hasil uji validitas variabel Citra Merek (X2) dapat dilihat pada tabel 2 sebagai berikut :

Tabel 2 Hasil Uji Validitas Variabel Citra Merek (X2)

\begin{tabular}{|c|c|}
\hline & Corrected Item-Total Correlation \\
\hline x201 &, 651 \\
\hline x202 &, 643 \\
\hline x203 &, 531 \\
\hline x204 &, 500 \\
\hline x205 &, 697 \\
\hline x206 &, 641 \\
\hline x207 &, 584 \\
\hline x208 &, 533 \\
\hline x209 &, 555 \\
\hline \multicolumn{2}{|c|}{ Sumber : Data Primer yang Diolah }
\end{tabular}

Berdasarkan tabel 2 diatas seluruh pertanyaan variabel Citra Merek (X2) dinyatakan valid dikarenakan seluruh nilai Correlation berada diatas nilai $\mathrm{r}$ tabel $(0,1986)$, dan seluruh item pernyataan dapat digunaan untuk pengujian selanjutnya.

\section{Uji Validitas Loyalitas Pelanggan (Y)}

Hasil uji validitas variabel Loyalitas Pelanggan (Y) dapat dilihat pada tabel 3 sebagai berikut:
Tabel 3 Hasil Uji Validitas Variabel Loyalitas

Pelanggan (Y)

\begin{tabular}{|c|c|}
\hline & Corrected Item-Total Correlation \\
\hline y01 &, 757 \\
\hline y02 &, 532 \\
\hline y03 &, 695 \\
\hline y04 &, 723 \\
\hline y05 &, 761 \\
\hline y06 &, 631 \\
\hline y07 &, 747 \\
\hline y08 &, 673 \\
\hline y09 &, 741 \\
\hline \multicolumn{2}{|c|}{ Sumber : Data Primer yang Diolah } \\
\hline
\end{tabular}

Berdasarkan tabel 3 diatas seluruh pertanyaan variabel Loyalitas Pelanggan (Y) dinyatakan valid dikarenakan seluruh nilai Correlation berada diatas nilai $r$ tabel $(0,1986)$, dan seluruh item pernyataan dapat digunaan untuk pengujian selanjutnya.

\section{Uji Reliabilitas}

Menurut Sugiyono (2012) yang menyebutkan bahwa Reliabilitas adalah serangkaian pengukuran atau serangkaian alat ukur yang memiliki konsistensi bila pengukuran yang dilakukan dengan alat ukur itu dilakukan secara berulang. Dengan menggunakan bantuan software SPSS maka koefisien cronbach's alpha merupakan uji reabilitas untuk alternatif jawaban lebih dari dua. Nilai tiap-tiap item sebaiknya $\geq$ 0.40 sehingga membuktikan bahwa item tersebut dapat dikatakan punya reliabilitas. Hasil uji reliabilitas dapat dilihat pada tabel 4 berikut ini :

Tabel 4 Uji Reliabilitas

\begin{tabular}{|c|c|c|}
\hline Variabel & CA & Item \\
\hline $\mathrm{X} 1$ & 0,757 & 15 \\
\hline $\mathrm{X} 2$ & 0,760 & 9 \\
\hline $\mathrm{Y}$ & 0,776 & 9 \\
\hline
\end{tabular}

Sumber : Data Primer yang Diolah

Dari penyajian table 4 diatas, maka seluruh variabel penelitian dinyatakan reliabel, dimana hasil perhitungan uji reliabilitas yang masing masing variabelnya menunjukan Cronbach's Alpha lebih besar dari 0,40. Hal ini berarti keseluruhan variabel dapat digunakan untuk pengolahan data lebih lanjut.

\section{Uji Normalitas}

Bertujuan untuk menguji apakah dalam model regresi variabel terikat dan variabel bebas keduanya mempunyai distribusi normal ataukah tidak. Model regresi yang baik adalah memiliki distribusi data normal atau mendekati normal. Dasar pengambilan keputusan dalam uji normalitas yakni jika nilai signifikansi lebih besar dari 0,05 , nilai ini diambil pada hasil uji nirmalitas menggunakan SPSS versi 20. 
Tabel 5 Hasil Uji Normalitas

\begin{tabular}{|c|c|c|}
\hline & $\begin{array}{c}\text { Unstandardize } \\
\text { d Residual }\end{array}$ \\
\hline \multicolumn{2}{|c|}{$\mathrm{N}$} & 96 \\
\hline \multirow{2}{*}{$\begin{array}{c}\text { Normal } \\
\text { Parametersa,b }\end{array}$} & Mean & $0 \mathrm{E}-7$ \\
\hline & Std. Deviation & 1,79970100 \\
\hline \multirow{3}{*}{$\begin{array}{l}\text { Most Extreme } \\
\text { Differences }\end{array}$} & Absolute & ,069 \\
\hline & Positive & ,066 \\
\hline & Negative &,- 069 \\
\hline \multicolumn{2}{|c|}{ Kolmogorov-Smirnov Z } & 675 \\
\hline \multicolumn{2}{|c|}{ Asymp. Sig. (2-tailed) } &, 752 \\
\hline
\end{tabular}

Sumber : Data Hasil Olahan SPSS v20

Dari tabel 5 didapatkan nilai residual sebesar 0,752 lebih besar dari 0,05 dari nilai sampel sebesar 96 yang berarti data yang sedang diuji berdistribusi normal. Selain menggunakan tabel diatas, juga dapat dengan melihat grafik histogram seperti gambar 6 dibawah ini :

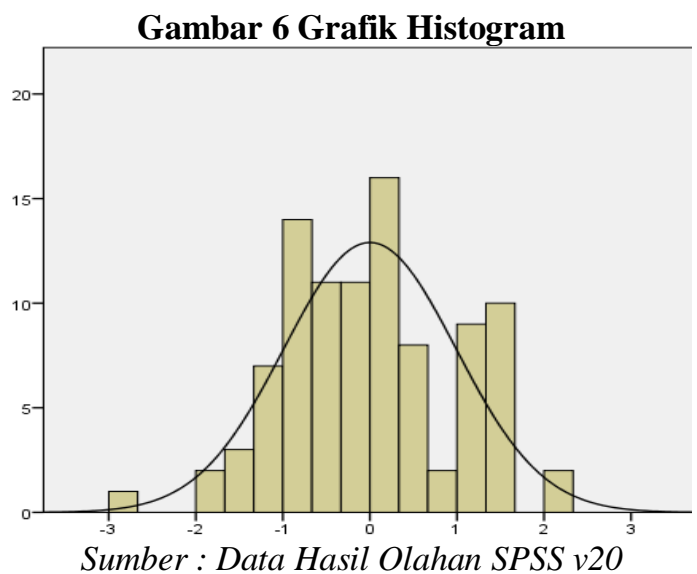

Berdasarkan tampilan gambar 6 diketahui grafik histogram memberikan pola distribusi yang melenceng ke kanan dan berarti data yang digunakan berdistribusi normal.

\section{Uji Multikolinearitas}

Multikolinearitas merupakan salah satu uji dari uji asumsi klasik yang merupakan pengujian yang dilakukan untuk mengidentifikasi suatu model regresi dapat dikatakan baik atau tidak. Uji multikolinearitas bertujuan untuk menguji apakah model regresi ditemukan adanya korelasi antar variabel bebas (independent). Model regresi yang baik seharusnya tidak terjadi korelasi diantara variabel bebas (tidak terjadi multikolinearitas). Hasil uji multikolinearitas pada penelitian ini dapat dilihat pada tabel 6 berikut :

Tabel 6 Hasil Uji Multikolinearitas

\begin{tabular}{|c|c|c|c|}
\hline \multicolumn{2}{|c|}{ Model } & \multicolumn{2}{c|}{ Collinearity Statistics } \\
\cline { 3 - 4 } \multicolumn{2}{|c|}{} & Tolerance & VIF \\
\hline \multirow{3}{*}{1} & (Constant) & & \\
\cline { 2 - 4 } & $\mathrm{x} 1$ &, 619 & 1,615 \\
\cline { 2 - 4 } & $\mathrm{x} 2$ &, 619 & 1,615 \\
\hline
\end{tabular}

Sumber : Data Hasil Olahan SPSS v20

Dari tabel 6 dapat disimpulkan bahwa semua variabel telah lolos dari uji multikolinearitas dengan penjabaran sebagai berikut :

1. Variabel $\mathrm{X} 1$ tidak terjadi multikolinearitas dikarenakan nilai VIF yang bernilai 1,615 lebih kecil dari 10,00, dan nilai Tolerance yang bernilai 0,619 lebih besar dari 0,10.

2. Variabel X2 tidak terjadi multikolinearitas dikarenakan nilai VIF yang bernilai 1,615 lebih kecil dari 10,00. dan nilai Tolerance yang bernilai 0,619 lebih besar dari 0,10.

\section{Uji Heteroskedastisitas}

Uji heterokedastisitas bertujuan menguji apakah dalam model regresi terjadi ketidaksamaan variance dari residual satu pengamatan ke pengamatan yang lain. Ada beberapa cara yang dapat dilakukan untuk melakukan uji heteroskedastisitas, yaitu uji grafik plot, uji park, uji glejser, dan uji white. Pengujian pada penelitian ini menggunakan Grafik Plot antara nilai prediksi variabel dependen yaitu ZPRED dengan residualnya SRESID. Tidak terjadi heteroskedastisitas apabila tidak ada pola yang jelas, serta titik-titik menyebar di atas dan di bawah angka 0 pada sumbu Y. (Imam Ghozali, 2015). Haslil uji heteroskedastisitas pada penelitian ini dapat dilihat pada gambar 7 berikut:

\section{Gambar 7 Hasil Uji Heteroskedastisitas}

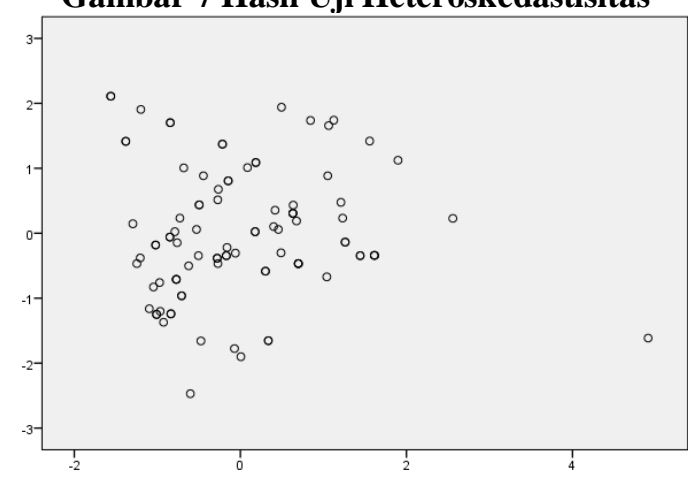

Sumber : Data Hasil Olahan SPSS v20

Dari gambar 7 di atas dapat disimpulkan bahwa titik-titik menyebar dan tidak membentuk pola tertentu yang jelas. Sehingga tidak terjadi heteroskedastisitas.

\section{Analisa Linear Berganda}

Hasil pengujian analisis regresi linier berganda pada penelitian ini diadopsi dari tabel coefficients yang dapat dilihat pada tabel 7 berikut ini.

\begin{tabular}{|c|c|c|c|c|}
\multicolumn{4}{c}{} & Tabel 7 Coefficients \\
\hline \multirow{2}{*}{ Model } & \multicolumn{2}{|c|}{$\begin{array}{c}\text { Unstandardized } \\
\text { Coefficients }\end{array}$} & $\begin{array}{c}\text { Standardized } \\
\text { Coefficients }\end{array}$ \\
\cline { 2 - 5 } \multicolumn{2}{|c|}{} & $\mathrm{B}$ & Std. Error & Beta \\
\hline \multirow{2}{*}{1} & Constant & 3,453 & 2,035 & \\
\cline { 2 - 5 } & $\mathrm{x} 1$ &, 293 &, 041 &, 408 \\
\hline
\end{tabular}




\begin{tabular}{|l|l|l|l|l|}
\hline & $\mathrm{x} 2$ &, 622 &, 061 &, 588 \\
\hline
\end{tabular}

Sumber: Data yang Diolah Dengan SPSS v20

Dari tabel 7 dapat ditarik persamaan regresinya sebagai berikut :

$\mathrm{Y}=3,453+0,293 \mathrm{X} 1+0,622 \mathrm{X} 2$

1. Nilai konstanta sebesar 3,453 berarti apabila variabel Switching Barrier dan Citra Merek sama dengan nol (0), maka variabel Loyalitas Pelanggan bernilai 3,453 satuan.

2. Nilai koefisien regresi variabel Switching Barrier sebesar 0,293, berarti bahwa koefesien ini bernilai positif. Peningkatan variabel Switching Barrier (X1) sebesar satu satuan maka Loyalitas Pelanggan (Y) akan meningkat sebesar 0,293. Kenaikan variabel Switching Barrier berakibat kenaikan pada variabel Loyalitas Pelanggan.

3. Nilai koefisien regresi variabel Citra Merek sebesar 0,622, berarti bahwa koefesien ini bernilai positif. Peningkatan variabel Citra Merek (X2) sebesar satu satuan maka variabel Loyalitas Pelanggan (Y) akan meningkat sebesar 0,622. Kenaikan variabel Citra Merek berakibat kenaikan pada variabel Loyalitas Pelanggan.

\section{Analsis Jalur (Path Analysis)}

Teknik analisis yang digunakan dalam penelitian ini adalah menggunakan analisis jalur (path analysis). Analisis jalur digunakan untuk menjawab hipotesis keempat dan kelima. Hasil pengolahan data menggunakan SPSS versi 20 mengenai pengaruh langsung dan tidak langsung dari variabel Switching Barrier dan terhadap Loyalitas Pelanggan melalui Citra Merek dan pengaruh Citra Merek terhadap Loyalitas Pelanggan melalui Switching Barrier dapat dijelaskan sebagai berikut.

1. Pengaruh switching barrier terhadap loyalitas pelanggan pada produk Interbis melalui citra merek di PT. Multimas Sumber Harapan Padang.

Untuk mengetahui pengaruh switching barrier terhadap loyalitas pelanggan pada produk Interbis melalui citra merek, hal pertama yang dilakukan adalah dengan melihat pengaruh switching barrier terhadap loyalitas pelanggan terlebih dahulu. Hasil tersebut dapat dilihat pada tabel 8 dan 9 :

Tabel 8 Hasil Analisa X1 Terhadap X2

\begin{tabular}{|c|c|c|c|c|}
\hline \multirow{2}{*}{ Model } & $\begin{array}{c}\text { Standardized } \\
\text { Coefficients }\end{array}$ & t & Sig. \\
\cline { 3 - 5 } \multicolumn{2}{|c|}{} & Beta & \\
\hline \multirow{2}{*}{1} & (Constant) & & 3,159 &, 002 \\
\cline { 2 - 5 } & $\mathrm{x} 1$ &, 617 & 7,604 &, 000 \\
\hline \multicolumn{2}{|c|}{ Sumber: Data yang Diolah Dengan SPSS v20 }
\end{tabular}

Tabel 9 Model Sumary I

\begin{tabular}{|c|c|c|}
\hline Model & R & R Square \\
\hline 1 &, $617 \mathrm{a}$ &, 381 \\
\hline
\end{tabular}

Sumber: Data yang Diolah Dengan SPSS v20

Berdasarkan tabel 8 terlihat bahwa nilai signifikansi switching barrier sebesar 0,000 yang mana kecil dari nilai $\alpha$, sehingga koefesien jalurnya signifikan. Karena koefisien jalurnya signifikan maka jalur dari X1 ke X2 terhubung. Dengan demikian diperoleh diagram jalur sebagai berikut :

\section{Gambar 8 Struktur Path I}

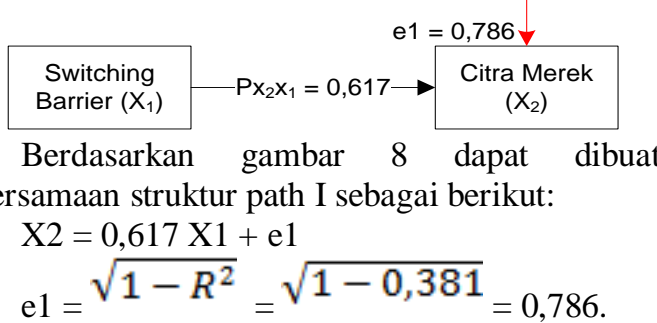

Setelah didapati pengaruh switching barrier terhadap citra merek, langkah selanjunya adalah melihat pengaruh switching barrier dan citra merek terhadap loyalitas pelanggan. Hasil analisis pathnya dapat dilihat pada tabel 10 dan 11 :

Tabel 10 Hasil Analisa X1 \& X2 Terhadap Y

\begin{tabular}{|c|c|c|c|c|}
\hline \multicolumn{2}{|c|}{ Model } & $\begin{array}{c}\text { Standardized } \\
\text { Coefficients }\end{array}$ & \multirow{2}{*}{ Sig. } & \\
\cline { 3 - 5 } \multicolumn{2}{|c|}{} & Beta & & \\
\hline \multirow{3}{*}{1} & (Constant) & & 1,697 &, 093 \\
\cline { 2 - 5 } & $\mathrm{x} 1$ &, 408 & 7,072 &, 000 \\
\cline { 2 - 5 } & $\mathrm{x} 2$ &, 588 & 10,200 &, 000 \\
\hline
\end{tabular}

Sumber: Data yang Diolah Dengan SPSS v20

Tabel 11 Model Sumary II

\begin{tabular}{|c|c|c|}
\hline Model & R & R Square \\
\hline 1 &, $899 \mathrm{a}$ &, 808 \\
\hline
\end{tabular}

Sumber: Data yang Diolah Dengan SPSS v20

Berdasarkan tabel 10 terlihat bahwa nilai signifikasi X1 dan X2 adalah 0,000 dimana lebih kecil dari $\alpha$ sehingga koefisien jalurnya signifikan. Karena koefisien jalurnya signifikan maka jalur dari X1 dan X2 menuju Y terhubung. Dengan demikian diperoleh diagram jalur sebagai berikut :

\section{Gambar 9 Struktur Path II}

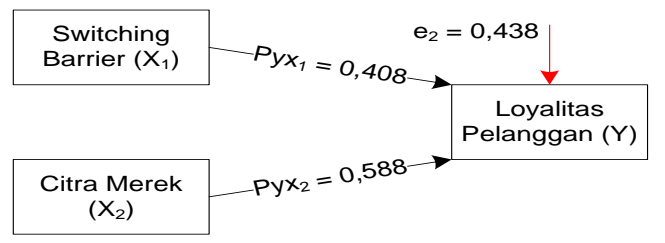

Berdasarkan gambar 9 dapat dibuat persamaan struktur path II sebagai berikut : 
$\mathrm{Y}=0,408 \mathrm{X} 1+0,588 \mathrm{X} 2+\mathrm{e} 2$

$\mathrm{e} 2=\sqrt{1-R^{2}}=\sqrt{1-0,808}=0,438$

Berdasarkan gambar 8 dan 9 dapat dibuat diagram jalur path secara utuh sebagai berikut :

Gambar 10 Struktur Path X1 melalui X2 terhadap Y

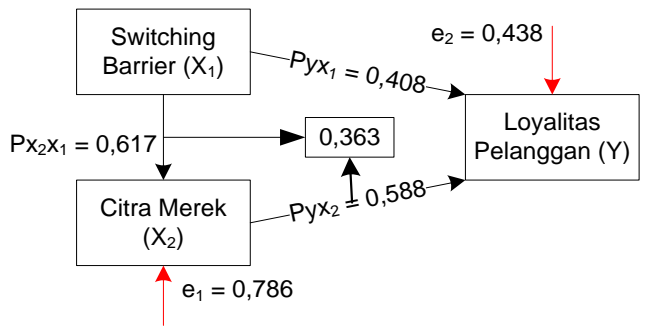

Dari gambar 10 dapat dijelaskan :

a. Pengaruh langsung switching barrier (X1) terhadap loyalitas pelanggan (Y) adalah sebesar 0,408 satuan.

b. Pengaruh langsung citra merek (X2) terhadap loyalitas pelanggan (Y) adalah sebesar 0,588 satuan.

c. Pengaruh langsung switching barrier (X1) terhadap citra merek (X2) adalah sebesar 0,617 satuan

d. Sedangkan pengaruh tidak langsung switching barrier terhadap loyalitas pelanggan melalui citra merek adalah sebesar 0,363 satuan.

2. Pengaruh citra merek terhadap loyalitas pelanggan pada produk Interbis melalui switching barrier di PT. Multimas Sumber Harapan Padang.

Untuk mengetahui pengaruh citra merek terhadap loyalitas pelanggan pada produk Interbis melalui switching barrier, hal pertama yang dilakukan adalah dengan melihat pengaruh citra merek terhadap switching barrier terlebih dahulu. Hasil tersebut dapat dilihat pada tabel 12 dan 13 :

Tabel 12 Hasil Analisa X2 Terhadap X1

\begin{tabular}{|c|c|c|c|c|}
\hline \multicolumn{2}{|c|}{ Model } & $\begin{array}{c}\text { Standardized } \\
\text { Coefficients }\end{array}$ & \multirow{2}{*}{ S } & \multirow{2}{*}{ Sig. } \\
\cline { 3 - 5 } \multicolumn{2}{|c|}{} & Beta & & \\
\hline \multirow{2}{*}{1} & (Constant) & & 6,443 &, 000 \\
\cline { 2 - 5 } & $\mathrm{x} 2$ &, 617 & 7,604 &, 000 \\
\hline
\end{tabular}

Sumber: Data yang Diolah Dengan SPSS v20

Tabel 13 Model Sumary III

\begin{tabular}{|c|c|c|}
\hline Model & R & R Square \\
\hline 1 &, $617 \mathrm{a}$ &, 381 \\
\hline
\end{tabular}

Sumber: Data yang Diolah Dengan SPSS v20

Berdasarkan tabel 12 terlihat bahwa nilai signifikansi citra merek sebesar 0,000 dimana lebih kecil dari nilai $\alpha$, sehingga koefisien jalurnya signifikan. Karena koefisien jalurnya signifikan maka jalur dari X2 ke X1 jalurnya terhubung. Dengan demikian diperoleh diagram jalur sebagai berikut :

\section{Gambar 11 Struktur Path X2 ke X1}

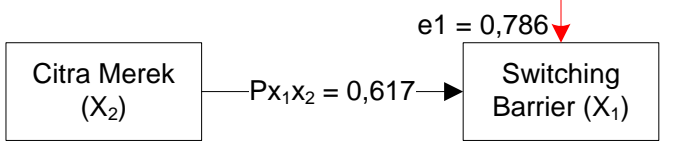

Berdasarkan gambar 11 dapat dibuat persamaan struktur path IV sebagai berikut:

$$
\begin{aligned}
& \mathrm{X} 1=0,617 \mathrm{X} 2 \\
& \mathrm{e} 1=\sqrt{1-R^{2}}=\sqrt{1-0,381}=0,786 .
\end{aligned}
$$

Setelah didapati pengaruh citra merek terhadap switching barrier, langkah selanjutnya adalah melihat pengaruh citra merek dan switching barrier terhadap loyalitas pelanggan. Hasil analisis pathnya dapat dilihat pada tabel 14 dan 15 :

Tabel 14 Hasil Analisa Jalur X2 dan X1 Terhadap Y

\begin{tabular}{|c|c|c|c|c|}
\hline \multicolumn{2}{|c|}{ Model } & $\begin{array}{c}\text { Standardized } \\
\text { Coefficients }\end{array}$ & \multirow{2}{*}{ t } & Sig. \\
\cline { 3 - 5 } \multicolumn{2}{|c|}{} & Beta & & \\
\hline \multirow{3}{*}{1} & (Constant) & & 1,697 &, 093 \\
\cline { 2 - 5 } & $\mathrm{x} 1$ &, 408 & 7,072 &, 000 \\
\cline { 2 - 5 } & $\mathrm{x} 2$ &, 588 & 10,200 &, 000 \\
\hline
\end{tabular}

Sumber: Data yang Diolah Dengan SPSS v20

Tabel 15 Model Sumary IV

\begin{tabular}{|c|c|c|}
\hline Model & R & R Square \\
\hline 1 &, $899 \mathrm{a}$ &, 808 \\
\hline
\end{tabular}

Sumber: Data yang Diolah Dengan SPSS v20

Berdasarkan tabel 14 dan 15 terlihat bahwa nilai signifikansi $\mathrm{X} 2$ dan $\mathrm{X} 1$ adalah 0,000 dimana lebih kecil dari a sehingga koefisien jalurnya signifikan. Karena koefisien jalurnya signifikan maka jalur dari X2 dan X1 menuju Y terhubung. Dengan demikian diperoleh diagram jalur sebagai berikut :

\section{Gambar 12 Struktur Path X2 dan X1 terhadap $Y$}

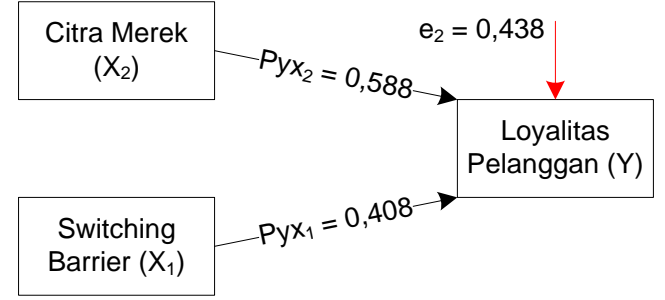

Berdasarkan gambar 12 dapat dibuat persamaan struktur path V sebagai berikut :

$$
\begin{aligned}
& \mathrm{Y}=0,588 \mathrm{X} 2+0,408 \mathrm{X} 1+\mathrm{e} 2 \\
& \mathrm{e} 2=\sqrt{1-R^{2}}=\sqrt{1-0,808}=0,438
\end{aligned}
$$


Berdasarkan gambar 11 dan 12 dapat dibuat diagram jalur path secara utuh sebagai berikut :

\section{Gambar 13 Struktur Path X2 melalui X1} terhadap Y

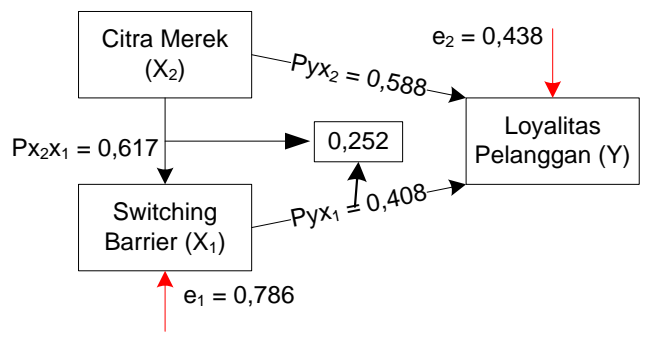

Dari gambar 13 dapat dijelaskan :

a. Pengaruh langsung citra merek (X2) terhadap loyalitas pelanggan (Y) adalah sebesar 0,588 satuan.

b. Pengaruh langsung switching barrier (X1) terhadap loyalitas pelanggan (Y) adalah sebesar 0,408 satuan.

c. Pengaruh langsung citra merek (X2) terhadap switching barrier (X1) adalah sebesar 0,617 satuan.

d. Sedangkan pengaruh tidak langsung citra merek terhadap loyalitas pelanggan melalui switching barrier adalah sebesar 0,252 satuan.

\section{Analisa Determinasi}

Koefisien determinasi dihitung dengan mengkuadratkan Koefisien Korelasi (R). Penggunakan R Square (R2) sering menimbulkan permasalahan, yaitu bahwa nilainya akan selalu meningkat dengan adanya penambahan variabel bebas dalam suatu model. Hal ini akan menimbulkan bias, karena jika ingin memperoleh model dengan $\mathrm{R}$ tinggi, oleh karena itu, banyak peneliti yang menyarankan untuk menggunakan Adjusted R Square. Interpretasinya sama dengan $\mathrm{R}$ Square, akan tetapi nilai Adjusted R Square dapat naik atau turun dengan adanya penambahan variabel baru, tergantung dari korelasi antara variabel bebas tambahan tersebut dengan variabel terikatnya (Santoso, 2010). Nilai Adjusted R Square dapat bernilai negatif, sehingga jika nilainya negatif, maka nilai tersebut dianggap 0 , atau variabel bebas sama sekali tidak mampu menjelaskan varians dari variabel terikatnya. Nilai koefisien determinasi dari variabel switching barrier dan citra merek terhadap loyalitas pelanggan dapat dilihat pada tabel 16 berikut ini :

Tabel 16 Koefesien Determinasi

\begin{tabular}{|c|c|c|c|}
\hline Model & R & R Square & $\begin{array}{c}\text { Adjusted R } \\
\text { Square }\end{array}$ \\
\hline 1 &, $899 \mathrm{a}$ &, 808 &, 804 \\
\hline
\end{tabular}

Sumber: Data yang Diolah Dengan SPSS v20
Berdasarkan tabel 16 terlihat nilai Adjusted R Square variabel independen, adalah sebesar 0,804. Berarti kemampuan variabel Switching Barrier dan Citra Merek dalam menjelaskan varians dari variabel Loyalitas Pelanggan adalah sebesar $80,4 \%$. Berarti terdapat $19,6 \%$ varians variabel Loyalitas Pelanggan yang dijelaskan oleh variabel lain.

\section{Uji t}

Uji $\mathrm{t}$ digunakan untuk menguji apakah terdapat pengaruh yang signifikan secara individual dari variabel bebas terhadap variabel terikat. Uji $\mathrm{t}$ digunakan untuk menjawab hipotesis pertama dan kedua. Hasil uji $t$ dari penelitian ini dapat disajikan pada tabel 17 berikut ini.

Tabel 17 Hasil Uji t

\begin{tabular}{|c|c|c|c|}
\hline \multicolumn{2}{|c|}{ Model } & T & Sig. \\
\hline \multirow{3}{*}{1} & (Constant) & 1,697 &, 093 \\
\cline { 2 - 4 } & $\mathrm{x} 1$ & 7,072 &, 000 \\
\cline { 2 - 4 } & $\mathrm{x} 2$ & 10,200 &, 000 \\
\hline
\end{tabular}

Sumber: Data yang Diolah Dengan SPSS v20

Dengan menggunakan tingkat signifikansi $0,05(\alpha=5 \%)$ dan $t$ tabel pada signifikansi 0,05 uji dua arah dengan derajat kebebasan df n-k-1 = 96-2-1 = 93 ( $\mathrm{n}$ adalah jumlah responden dan $\mathrm{k}$ adalah jumlah variabel bebas) dengan nilai $t$ tabel sebesar 1,985 (lihat lampiran table t). Hasil uji t dapat dilihat pada output SPSS dari tabel 4.19. di atas diketahui sebagai berikut :

1. Variable Switching Barrier memiliki t hitung $(7,072)>t$ tabel $(1,985)$ dan nilai sig perhitungan yang diperoleh adalah sebesar $0,000<0,05$ jadi Ho ditolak Ha diterima. Dengan demikian dapat disimpulkan bahwa Switching Barrier secara individual berpengaruh signifikan terhadap Loyalitas Pelanggan.

2. Variable Citra Merek memiliki t hitung $(10,200)>t$ tabel $(1,985)$ dan nilai sig perhitungan yang diperoleh adalah sebesar $0,000<0,05$ jadi Ho ditolak Ha diterima. Dengan demikian dapat disimpulkan bahwa Citra Merek secara individual berpengaruh signifikan terhadap Loyalitas Pelanggan.

\section{Uji F}

Uji $\mathrm{F}$ dilakukan dengan melihat nilai $\mathrm{F}$ hitung dan nilai sig. Uji $\mathrm{F}$ digunakan untuk menjawab hipotesis ketiga. Tabel ANOVA dari output SPSS. Hasil pengujian disajikan pada tabel 18.

Tabel 18 ANOVA

\begin{tabular}{|c|c|c|c|c|c|}
\hline \multicolumn{2}{|c|}{ Model } & $\begin{array}{c}\text { Sum of } \\
\text { Squares }\end{array}$ & df & F & Sig. \\
\hline \multirow{3}{*}{1} & Regression & 1298,927 & 2 & 196,297 &, $000 \mathrm{~b}$ \\
\cline { 2 - 6 } & Residual & 307,698 & 93 & & \\
\cline { 2 - 6 } & Total & 1606,625 & 95 & & \\
\hline
\end{tabular}


Sumber: Data yang Diolah Dengan SPSS v20

Dari tabel tersebut diketahui nilai $\mathrm{F}$ hitung 196,297 yang lebih besar dari nilai $F$ tabel sebesar 3,94 (lihat lampiran tabel F) dan nilai probabilitas yang dihasilkan dari perhitungan adalah 0,000 lebih kecil dari $\alpha(5 \%)$. Dengan demikian dapat disimpulkan variabel Switching Barrier dan Citra Merek secara bersama-sama atau simultan berpengaruh signifikan terhadap Loyalitas Pelanggan.

\section{KESIMPULAN \\ Kesimpulan}

Berdasarkan hasil analisis dan pembahasan mengenai pengaruh Switching Barrier (X1) dan Citra Merek (X2) terhadap Loyalitas Pelanggan (Y), maka dapat ditarik kesimpulan sebagai berikut :

1. Switching Barrier berpengaruh positif dan signifikan terhadap Loyalitas Pelanggan karena t hitung 7,020 lebih besar dari t tabel dan nilai sig 0,000 lebih kecil dari $\alpha(0,05)$.

2. Citra Merek berpengaruh positif dan signifikan terhadap Loyalitas Pelanggan karena t hitung 10,200 lebih besar dari t tabel dan nilai sig 0,000 lebih kecil dari $\alpha(0,05)$.

3. Switching Barrier (X1) dan Citra Merek (X2) berpengaruh signifikan secara bersama sama terhadap Loyalitas Pelanggan (Y) karena F hitung 196,297 lebih besar dari F tabel dan nilai sig 0,000 lebih kecil dari $\alpha(0,05)$.

4. Switching Barrier secara langsung berpengaruh signifikan terhadap Loyalitas Pelanggan PT. Multimas Sumber Harapan Padang melalui Citra Merek dengan persamaan $\mathrm{Y}=0,408 \mathrm{X} 1+0,588 \mathrm{X} 2+$ $0,438 \mathrm{e} 2$.

5. Citra Merek secara langsung berpengaruh signifikan terhadap Loyalitas Pelanggan PT. Multimas Sumber Harapan Padang melalui Switching Barrier dengan persamaan $\mathrm{Y}=$ $0,588 \mathrm{X} 2+0,408 \mathrm{X} 1+0,438 \mathrm{e} 2$.

6. Hasil analisis determinasi diperoleh angka Adjusted R Square sebesar 0,804 atau sebesar $80,4 \%$. Hal ini menunjukan persentase sumbangan variabel Switching Barrier (X1) dan Citra Merek (X2) terhadap Loyalitas Pelanggan (Y) sebesar 80,4\% dan sisanya sebesar $19,6 \%$ dipengaruhi varibel diluar penelitian seperti kualitas produk, harga dan lain lain.

\section{Saran}

Berdasarkan kesimpulan di atas, dapat dikemukakan beberapa saran yang diharapkan dapat bermanfat bagi perusahaan atau pihak lain yang berkepentingan. Adapun saran yang diberikan, antara lain :

1. Bagi perusahaan, dari hasil penelitian ini dapat dijadikan sebagai salah satu pertimbangan dalam pengambilan keputusan, terutama keputusan mengenai kebijakan pemasaran perusahaan.

2. Bagi akademik, diharapkan bagi peneliti selanjutnya yang akan meneliti tentang Loyalitas Pelanggan untuk menambah variasi variabel independen yang digunakan dan menambah jumlah perusahaan yang diteliti.

\section{DAFTAR REFERENSI}

\section{Buku}

Agussalim Manguluang, 2015. Statistik Lanjutan, Ekasakti Press, Padang

Ali Hasan. 2017. Marketing. Media Utama, Yogyakarta

Arikunto, S. 2012. Prosedur Penelitian: Suatu Pendekatan Praktek. Jakarta: Rineka Cipta

Ghozali, Imam. 2015. Aplikasi Analisis Multivariate Dengan Program IBM. SPSS 19 (edisi kelima.) Semarang: Universitas Diponegoro.

Griffin, Jill. 2015. Customer Loyalty : Menumbuhkan dan Mempertahankan. Kesetiaan Pelanggan. Alih bahasa : Dwi Kartini Yahya dan kawan kawan. Erlangga, Jakarta.

Kotler, Philip, dan Gary Armstrong. 2015. Prinsip Prinsip Pemasaran. Jakarta: Erlangga

Kotler dan Keller. 2015. Manajemen Pemasaran. Jilid I. Edisi ke 16 Jakarta: Erlangg.

Sugiyono. 2017. Metode Penelitian Bisnis. Bandung: Alfabeta.

Supriadi, Setiawan. 2015. "Loyalitas Pelanggan Jasa'Studi Kasus Bagaimana Rumah Sakit Mengelola Loyalitas Pelanggannya. Bogor: PT. Penerbit IPB Press

Tjiptono, Fandy, Gregorius Chandra, dan Dadi Adriana. 2015. Pemasaran Strategik. Yogyakarta: Andi

\section{Jurnal Nasional}

Arlan, Tjahyadi Rully. 2015. Brand Trust Dalam Konteks Karakteristik Merek, Karakteristik Perusahaan dan Pelanggan Merek. Jurnal Ekonomi UNIKOM Volume 2 No 1, hal 1-19

Gusti Ayu Putu Ratih Kusuma Dewi, 2017, Pengaruh Kualitas Pelayanan Terhadap Kepuasan Dan Loyalitas Nasabah PT Bpr Hoki Di Kab Tabanan, Jurnal Ekonomi Universitas Udayana Volume 4 No 1, hal 115

Pusporini, Niken. 2015. Analisis Pengaruh Customer Satisfaction, Switching Barrier, dan Trust In Brand Terhadap Customer Retention (Studi Kasus: Pengguna Kartu Seluler IM3 Pada Mahasiswa Fakultas Ekonomi Universitas Sebelas Maret Surakarta). Jurnal Fakultas Ekonomi Universitas Sebelas Maret Volume 12 No 1. 
hal 1-15

Muhammad Romadhoni, 2015. Pengaruh Citra Merek (Brand Image) Terhadap Pengambilan Keputusan Pembelian Sepatu Nike Pada Mahasiswa Fik Uny. Jurnal Fakultas Ekonomi Universitas Negeri Yogyakarta Volume 13 No 2. hal 16-33

Nandya Ayu Putri. 2016. Pengaruh Citra Merek, Kepercayaan Merek, Dan Switching Barrier Terhadap Kepuasan Pelanggan Dan Dampaknya Pada Loyalitas Pelanggan (Survei Pada Mahasiswa S1 Jurusan Ilmu Administrasi Bisnis Fakultas Ilmu Administrasi Universitas Brawijaya Tahun 2014/2015, Jurnal Administrasi Bisnis Universitas Brawijaya Volume 31 No 1, hal $1-19$

\section{Jurnal Internasional}

Chung-Tzer Liu, 2017, The effects of relationship quality and switching barriers on customer loyalty, International Journal of
Information Management Volume 31 No 1, hal 1-17

Klara Kövesi, 2015, The effect of switching barriers on customer engagement: an application to the mobile phone services, International Journal of Business and Management Invention Volume 4 Issue 4, hal 38-51

Seiedeh Nasrin Danesh, 2015, The Study of Customer Satisfaction, Customer Trust and Switching Barriers on Customer Retention in Malaysia Hypermarkets, International Journal of Business and Managemen Volume 7 No 7, hal 142-153

Tundung Subali Padma, 2016, The Influence Of Relationship Marketing On Switching Barrier, Customer Satisfaction, Customer Trust, And Customer Retention, International Journal of Business and Management Invention Volume 5 Issue 8, hal 162-178. 